\title{
The biotechnology sector in science and research in Wielkopolska Province: the current state and prospects for the future
}

\author{
EWA WOŹNIAK \\ Faculty of Geographical and Geological Sciences, Institute of Socio-Economic Geography and Spatial Management, \\ Adam Mickiewicz University in Poznan, Poznań, Poland
}

\begin{abstract}
The biotechnology sector in Poland is currently at its initial stage of development. Year by year, this field experiences an increase in research and development activity. Changes are being experienced not only at a country's level but also at a regional level. The strategic documents of Wielkopolska Province increasingly focus on the necessity to develop innovation and biotechnology. This region has a high potential for biotechnology development; however, its influence on the economy is still negligible. The aim of this article was to show the current state of the biotechnology sector in Wielkopolska Province and to analyze its development during 2011-2013. The analysis covered scientific units and enterprises that conducted research and development activity (R\&D) in the field of biotechnology as well as employees in scientific units and enterprises in R\&D activity. The sector has also been described on the basis of internal expenditures incurred totally by all units. In Wielkopolska Province, the internal expenditures of scientific units for pursuing R\&D activity in the field of biotechnology totaled PLN 26 million. On the other hand, the internal expenditures of enterprises on the biotechnological activity equaled PLN 67 million. The review of selected strategic documents shows the importance of biotechnology and its potential for development in Wielkopolska Province.
\end{abstract}

Key words: biotechnology, internal expenditure, Wielkopolska, research and development activity

\section{Introduction}

Biotechnology is an emerging sector of the Polish economy. In other parts of the world, this sector is marked by high competitiveness, high profits, fast market changes, and also continuous growing costs of research and development work. More and more enterprises keep constantly emerging whose activity relies on biotechnology and scientific research. These companies are characterized by high innovativeness. A criterion that is highly important in the development of the biotechnological industry is effective and efficient transfer of technology as well as the activity of scientific centers and higher education institutions.

In Poland, biotechnology is at its initial stage of development, but it is developing dynamically, and it constitutes the basis of the development of Polish economy.
It is predicted that in the future, the domestic biotechnological market will grow enormously. This growth will be the result of the implementation of innovative research projects by Polish enterprises and scientific units which will in this way contribute to the national economy. Additionally, an inflow of foreign investments related to this sector is also expected.

The aim of this article was to show the current state of the biotechnological sector in Wielkopolska Province and to investigate the development directions in the field of biotechnology that are recommended by the regional authorities. The time range encompasses 2011-2013. The analyzes took into account the number of scientific units and enterprises that conducted research and development activity $(\mathrm{R} \& \mathrm{D})$ in the field of biotechnology during 2011-2013 as well as people employed in R\&D in 
scientific units and enterprises and their internal expenditures. This article refers to the strategic documents that emphasize a necessity to develop biotechnology.

\section{Materials and methods}

The study used materials published by the Central Statistical Office of Poland (CSO, www.stat.gov.pl). The data included scientific units and enterprises associated with biotechnology, the employment figures in this sector, and the cost of internal expenditure in the abovementioned units in Wielkopolska Province. The data have been presented graphically as tables and figures. The data about biotechnological companies have been retrieved from the website www.biotechnologia.pl on June 30, 2015.

The strategic documents of Wielkopolska Province, such as the Wielkopolska Province Development Strategy 2020 or the Regional Innovation Strategy for Wielkopolska 2010-2020, were important sources of information. The documents helped to describe the role of the biotechnological sector in this region.

This article presents the following aspects of the state of the biotechnological sector in Wielkopolska Province during 2011-2013: the number of scientific units and enterprises, employment figures and internal expenditures, and their comparison with other regions of Poland, showing the best and the worst performances.

\section{Results and discussion}

\section{Concept of Biotechnology}

According to the report on the state and directions of development of bioeconomy, biotechnology is defined as "an interdisciplinary field of science and technology, which changes the animate and the inanimate matter through the use of living organisms, their elements or products, as well as models of biological processes with the aim of creating knowledge, goods and services" (Ministry of Science and Higher Education Report, 2007). According to OECD classification, biotechnology is divided on the basis of three fields of science:

- in engineering and technology (e.g., environmental and industrial biotechnologies);

- in medical sciences (e.g., medical biotechnology); and

- in agricultural sciences (e.g., agricultural biotechno$\operatorname{logy})$.
A wide range of technical applications of biological materials and processes in the production of goods and services, including both modern and traditional biotechnology, are available. Biotechnological technologies encompass, among other things, bioinformatics, nanotechnology, and technologies connected with DNA, proteins, and cells.

The authors of the report (Ministry of Science and Higher Education Report, 2007) also drew attention to the definition of a biotechnological enterprise. According to them, biotechnological enterprise is "an enterprise which conducts noticeable production activity in biotechnology and whose research and development activity related to biotechnology is carried out systematically in order to increase knowledge and economic applications of this knowledge."

\section{Place of biotechnology in the strategic documents of Wielkopolska Province}

In strategic documents, such as the Wielkopolska Province Development Strategy 2020 or the Regional Innovation Strategy for Wielkopolska 2010-2020, fragments refer to biotechnological development in Wielkopolska Province. According to this document, conditions for the development of biotechnology in the region are favorable. However, only a slight effect of scientific and research potential on innovations and the development of economy in this direction can be noted.

In the Wielkopolska Province Development Strategy 2020 (Development Strategy, 2012), enhancement of the role of science and research for innovation and economic development is one of the operational objectives. An important activity along these lines is supporting biotechnological research and strengthening R\&D units that specialize in biochemistry, biotechnology, or nanotechnology. The document highlights that the so-called smart specializations have prospects of development due to the activation of scientific and research potential in the technological direction, in industries such as in sectors of chemistry and information technology, or disciplines like nanotechnology, biotechnology, and biochemistry.

From the perspective of the development of biotechnology in this province, it is substantial to strengthen scientific and research personnel and to increase R\&D expenditures and cooperation between science and business. An important activity is supporting the commercialization of products and services from innovative indus- 
tries. Commercialization is the process of implementation and provision of an innovative product (technology and service) to clients. According to the Center for Technology Transfer of University of Lodz, "commercialization is the entire range of actions aimed at transferring knowledge from a laboratory to the market" (Łobejko, Sosnowska, 2013). Commercialization can refer both to a product and to a technology. It constitutes an important link of the previously discussed innovation value chain.

The Regional Innovation Strategy for Wielkopolska 2010-2020 (Regional Strategy, 2011) describes assumptions and a way of implementation of the innovation policy in the region. An increased influence of science on the economic development of the region is the main goal of the strategic program for cooperation between science and economy. This aim may be achieved by supporting the actions and facilitating the steps taken to obtain sources of funding. The document points out that entrepreneurship should be primarily encouraged in the scientific sector, which will favor the efficiency of cooperation and the transfer of knowledge and technologies from scientific and research units. Enhancing the scientific potential in Wielkopolska Province will create its competitive advantage.

\section{State of the biotechnological sector in Wielkopolska Pro- vince}

Scientific units conducting R\&D activity in the field of biotechnology have been divided into the state sector and higher education sector. The state sector includes departments and offices providing public services to citizens and non-commercial institutions that are controlled by the state and not managed by the higher education sector. On the other hand, the higher education sector consists of universities and technical schools that offer education at a level higher than the secondary one. The sector of non-commercial private institutions includes non-market-based private institutions that serve the public (CSO, 2015).

In 2013 in Wielkopolska Province, in total, there were 12 scientific units that conducted research and development activity in the field of biotechnology (Fig. 1). At the same time in Poland, there were 112 such units. Mazovia Province performed best with its 31 scientific units in 2013. The fewest scientific units were located in Opole Province - 3 units. According to the classification

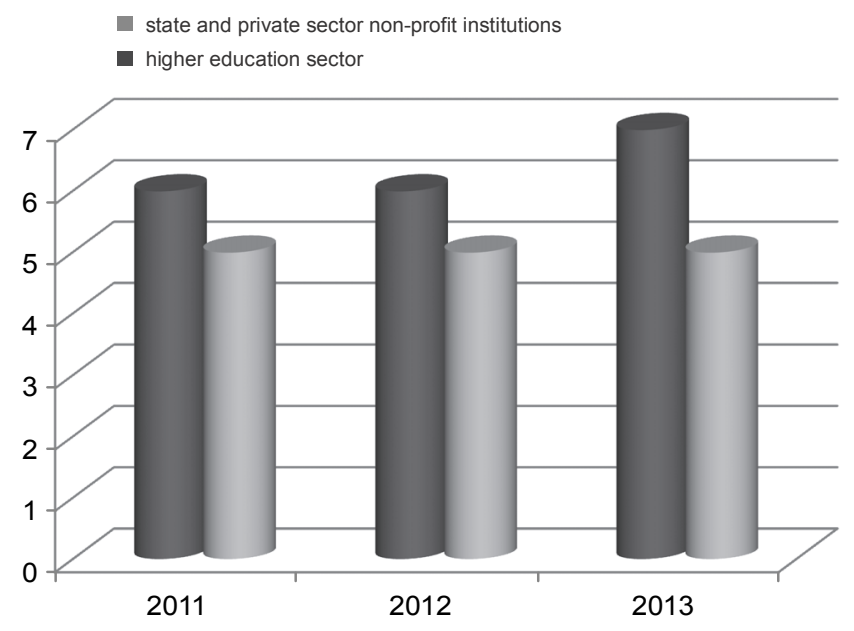

Fig. 1. The number of scientific units that conducted research and development activity (R\&D) in the field of biotechnology in Wielkopolska Province (2013)

Source: own study on the basis of the data from the CSO

of units into the state sector and private institutions, in Wielkopolska Province, 7 units operated under state and private institutions sector and 5 units under higher education sector. In 2011-2013, the number of higher education sector units both in Poland and in Wielkopolska Province was constant.

Three types of research and development activity in the field of technology can be distinguished - basic research, applied and industrial research, and development work. Basic research includes theoretical and experimental work carried out in order to expand knowledge, with no purpose of achieving economic profits. Applied research refers to research work that aims to gain new knowledge that has a practical use. Industrial research also aims to gain new knowledge and skills with the aim of preparing new products, processes, and services or their improvements. Development work refers to construction, technological, and design as well as experimental work that employ the existing knowledge obtained from research to develop new materials, processes, and services (CSO, 2015).

In 2013 in Wielkopolska Province, there were 11 scientific units that conducted basic scientific research (Table 1). Research constituted $46 \%$ of all types of R\&D activity. Development work was carried out by 6 units and applied and industrial scientific research by 7 scientific units. In Poland, scientific research was conducted by 97 units. Applied and industrial research was carried out by 76 units and development work by 61 . Mazovia 
Table 1. The number of scientific units by the type of research and development activity in the field of biotechnology in Wielkopolska Province and Poland in 2011-2013

\begin{tabular}{|c|c|c|c|c|c|c|c|c|c|}
\hline \multirow{2}{*}{ Territorial unit } & \multicolumn{3}{|c|}{ Basic research } & \multicolumn{3}{|c|}{$\begin{array}{l}\text { Applied research } \\
\text { and industrial }\end{array}$} & \multicolumn{3}{|c|}{ Development works } \\
\hline & 2011 & 2012 & 2013 & 2011 & 2012 & 2013 & 2011 & 2012 & 2013 \\
\hline Poland & 91 & 92 & 97 & 72 & 71 & 76 & 63 & 55 & 61 \\
\hline Wielkopolska Province & 10 & 10 & 11 & 6 & 5 & 7 & 5 & 5 & 6 \\
\hline Mazovia Province & 29 & 29 & 26 & 18 & 19 & 22 & 18 & 18 & 17 \\
\hline Opole Province & 0 & 0 & 3 & 0 & 0 & 0 & 0 & 0 & 0 \\
\hline
\end{tabular}

Source: own study on the basis of the data from the CSO

Table 2. The number of enterprises involved in biotechnological activities in Wielkopolska Province and Poland in 2011-2013

\begin{tabular}{|c|c|c|c|c|c|c|c|c|c|c|c|c|}
\hline \multirow[t]{2}{*}{ Territorial unit } & \multicolumn{3}{|c|}{ Total } & \multicolumn{3}{|c|}{$\begin{array}{l}\text { Total number } \\
\text { of enterprises } \\
\text { conducting } \\
\text { R\&D activity }\end{array}$} & \multicolumn{3}{|c|}{49 or less employees } & \multicolumn{3}{|c|}{$\begin{array}{l}50 \text { or more } \\
\text { employees }\end{array}$} \\
\hline & 2011 & 2012 & 2013 & 2011 & 2012 & 2013 & 2011 & 2012 & 2013 & 2011 & 2012 & 2013 \\
\hline Poland & 91 & 90 & 122 & 54 & 54 & 79 & 52 & 54 & 73 & 39 & 36 & 49 \\
\hline Wielkopolska Province & 13 & 14 & 21 & 8 & 9 & 14 & 6 & 10 & 16 & 7 & 4 & 5 \\
\hline Silesia Province & 8 & 12 & 15 & 0 & 7 & 10 & 3 & 7 & 6 & 5 & 5 & 9 \\
\hline Lower Silesia Province & 18 & 13 & 19 & 11 & 7 & 10 & 12 & 7 & 7 & 6 & 6 & 12 \\
\hline
\end{tabular}

Source: own study on the basis of the data from the CSO

Province stands out from other provinces as it has more number of units in the division that focus on all the three types of activity. On the other hand, lesser numbers of units are found in Opolskie, Kujawy-Pomerania, and Podkarpacie Provinces -3 units in each province that carry only basic research.

Internal expenditures refer to all expenditures on $\mathrm{R} \& \mathrm{D}$ activity conducted by a given statistical unit, irrespective of the source of finance. According to the data from the CSO, in 2013, internal expenditure on R\&D activity by scientific units in the field of biotechnology was found to be the highest in Mazovia Province, where it accounted for $42 \%$ of all the expenditures in Poland (PLN 173 million). In Poland, the expenditures amounted to more than PLN 413 million in 2013. The scientific units from Wielkopolska Province ranked fifth in terms of expenditures that amounted to approx. PLN 26 million and increased by 2 million compared to 2012. Funding was received from the European Union, international organizations, and foreign institutions. A total of more than 97 million PLN for Polish scientific units were from funds from abroad.
On the other hand, internal expenditures on R\&D activity in biotechnology field incurred by Polish enterprises exceeded PLN 483 million in 2013. Foreign funds amounted to 80 million PLN. Similar to the case of scientific units, the expenditures were the highest in Mazovia Province - more than PLN 105 million that constituted $22 \%$ of all the expenditures. Available data show that in 2013 about $3 \%$ of the expenditures were incurred by biotechnological enterprises in Lublin Province. In Wielkopolska Province, the expenditures were PLN 67 million and increased by 29 million compared to 2012. The internal expenditures on R\&D activity in the enterprises located in Wielkopolska Province accounted for $19.5 \%$ of all the expenditures in all enterprises of the province.

In 2013 in Wielkopolska Province, biotechnological activity was carried out by 21 enterprises (Table 2). Most of them dealt with research and development and employed up to 49 staff each. The same trend could be observed in Poland. Wielkopolska Province is among the regions having the largest number of enterprises. Lower Silesia Province also has many enterprises (19), followed 
Table 3. Companies operating in the field of biotechnology in Wielkopolska Province (as of June 30, 2015)

\begin{tabular}{|c|c|c|}
\hline Lp. & Name of company & Activity \\
\hline 1. & Argenta Spółka z ograniczoną odpowiedzialnością Sp.k & \multirow{3}{*}{$\begin{array}{c}\text { Sale of materials } \\
\text { and reagents }\end{array}$} \\
\hline 2. & MERANCO Aparatura Kontrolno-Pomiarowa i Laboratoryjna Sp. z o.o. & \\
\hline 3. & SIGMA-ALDRICH Sp. z o.o. & \\
\hline 4. & Bruker Polska Sp. z o.o. Aparatura naukowo-badawcza & \multirow{6}{*}{$\begin{array}{c}\text { Apparatus } \\
\text { and equipment }\end{array}$} \\
\hline 5. & Carl Zeiss Sp. z o.o. & \\
\hline 6. & MERANCO Aparatura Kontrolno-Pomiarowa i Laboratoryjna Sp. z o.o. & \\
\hline 7. & RHL - Service & \\
\hline 8. & SARTORIUS STEDIM POLAND Sp. $z$ o.o. / SARTORIUS POLAND Sp. $z$ o. o. & \\
\hline 9. & SIGMA-ALDRICH Sp. $z$ o.o. & \\
\hline 10. & AZELIS POLAND Sp. $z$ o.o. & \multirow{7}{*}{ Cosmetics } \\
\hline 11. & BASF Construction Chemicals Polska Sp. z o.o. & \\
\hline 12. & Cosmetics Partner & \\
\hline 13. & Kaczmarek - Komponenty & \\
\hline 14. & LCW Polska Sp. z o.o. & \\
\hline 15. & Provital Polska Sp. z o.o. & \\
\hline 16. & Stockmeier Chemia Sp. z o.o. & \\
\hline 17. & Centrum Badań DNA Sp. z o.o. & \multirow{3}{*}{$\begin{array}{l}\text { Service } \\
\text { companies }\end{array}$} \\
\hline 18. & Cosmeticlab.pl & \\
\hline 19. & VitalnSilica Sp. z o.o. & \\
\hline 20. & Wyższa Szkoła Zdrowia, Urody i Edukacji & \multirow{6}{*}{ Universities } \\
\hline 21. & Wyższa Szkoła Komunikacji i Zarządzania & \\
\hline 22. & Wydział Biologii Uniwersytet im. Adama Mickiewicza & \\
\hline 23. & Uniwersytet Przyrodniczy w Poznaniu; Wydział Rolnictwa i Bioinżynierii & \\
\hline 24. & Uniwersytet Medyczny im. Karola Marcinkowskiego w Poznaniu; Wydział Lekarski II & \\
\hline 25. & Politechnika Poznańska & \\
\hline 26. & Centrum Edukacji Biomedycznej Sp. z o.o. & \multirow{4}{*}{ Consulting } \\
\hline 27. & GxP Pharm Centrum Dobrych Praktyk & \\
\hline 28. & Ideas4biology Sp. z o.o. & \\
\hline 29. & TÜV Rheinland Polska Sp. z.o.o & \\
\hline 30. & VitalnSilica Sp. z o.o. & Software \\
\hline
\end{tabular}

Source: own study on the basis of the data accessed from www.biotechnologia.pl and Kalbarczyk, 2015

by Silesia Province (15 enterprises) and Pomerania Province (14 enterprises). Warmia-Masuria Province (4 enterprises) and Opole Province (3 enterprises) have few enterprises.

The website www.biotechnologia.pl gives different number of enterprises than CSO (Table 3). The enterprises operating in Wielkopolska Province are divided into those that produce materials and reagents for labo- ratories (3 enterprises), offer instruments and equipment ( 6 enterprises) or cosmetic raw materials ( 7 enterprises), provide biotechnological services (3 enterprises), and those that serve as higher education institutions for scientists (3 units), consultancies (3 enterprises), or a software enterprise (1 enterprise).

The company GlaxoSmithKline (GSK) is a good example of an enterprise that invests in pharmaceutical in- 


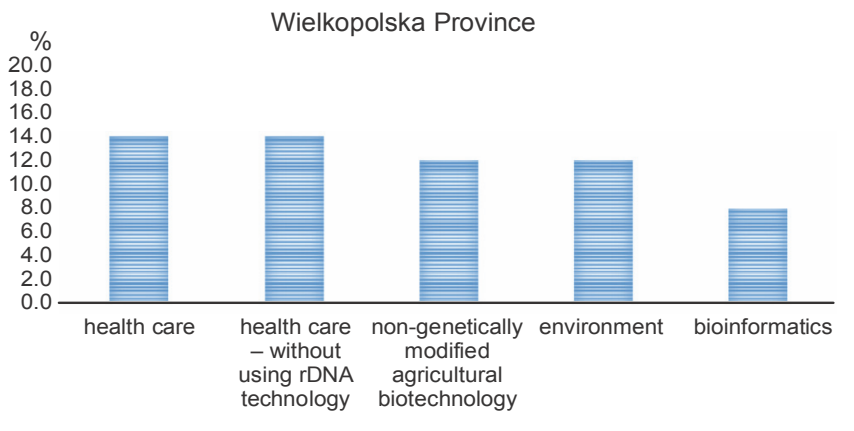

The main areas of activity in the field of biotechnology indicated by scientific units

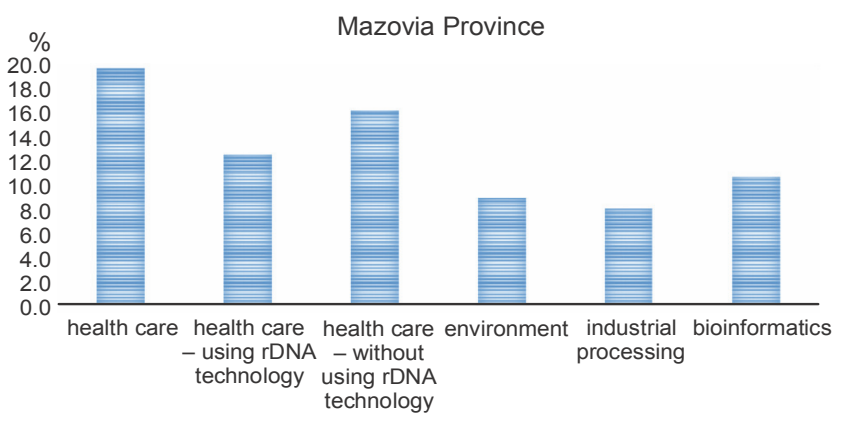

The main areas of activity in the field of biotechnology indicated by scientific units

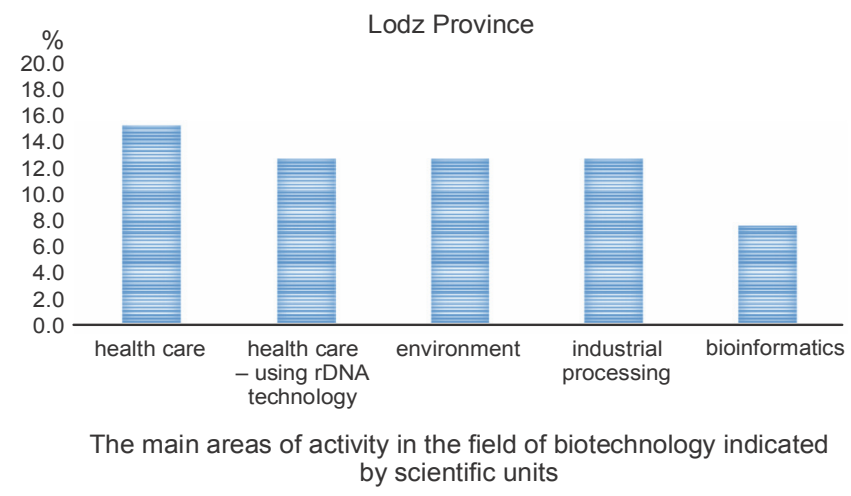

Source: own study on the basis of the data from the CSO

Fig. 2. Activity areas in the field of biotechnology indicated by scientific units (2013)

dustry. GSK is a leader in the pharmaceutical trade/industry in Poland. The factory in Poznan is one of the two in the world and the only European GSK manufacturing facility that produces medicine in a soft gelatinous capsules form (www.gsk.com.pl). Another example of biotechnological service is the Application Development and Maintenance Delivery (ADMD) department, which is a part of Roche's global IT structures. They deliver innovation in creating and maintaining solutions for Roche sites around the world. ADMD employs 726 people and have offices in Warsaw and Poznan (Roche Report, 2014). DNA Research Center is a company located in the Tech- nology Park in Poznan. It is a research and diagnostic center whose aim is to implement and offer new technologies in the field of DNA analysis. The center offers few services associated with genetic and cancer predisposition, paternity testing, and tick testing (www.cbdna.eu).

The major areas of activity of scientific units located in Wielkopolska Province are as follows: health protection with and without the use of rDNA technology and environment and non-GM agricultural biotechnology (Fig. 2).

The areas of activity in the biotechnology field differ across Poland. For the purposes of comparison, only those provinces where large numbers of scientific units are present have been selected. In Mazovia Province, there prevailed units dealing with health protection, bioinformatics, and industrial processing. Some of the biggest pharmaceutical companies, such as Roche, Pfizer, KRKA, or Servier, are located in the capital of Mazovia Province - Warsaw. In Lodz Province, the areas of activity were related to health protection (15\% of all biotech companies in region), environment, or industrial processing. The pharmaceutical company Adamed from Pabianice in 2013 had a $3 \%$ share of the market. The company was one of the biggest pharmaceutical companies in Poland (Polish Information and Foreign Investment Agency, 2011).

In 2011-2013, both in Poland and in Wielkopolska Province, a growth in the number of the people employed in research and development was observed (Table 4). The number of female employees in the above-indicated years increased systematically. It should be noted that the majority of workers employed in the field of biotechnology were women (64\%). In 2013, a larger number of employees were found to be employed in Mazovia Province - 2214 people, of whom $66 \%$ were women. In terms of the number of employees, Lodz Province ranked second -486 people. Nearly $70 \%$ of all the employees were women.

The Central Statistical Office of Poland (CSO) defines the people employed in $R \& D$ as employees directly connected with research and development activity who devote at least $10 \%$ of their work time to this activity. In 2013 in Wielkopolska Province, of the 446 people who worked in the field of biotechnology, a majority were holders of a doctor's degree (39\%) or graduates with higher education (37\%) (Table 5). A similar trend was observed throughout the country for employee's qualification, where employees with a doctor's degree ac- 
Table 4. The number of people employed in research and development (R\&D) in the field of biotechnology in scientific units in Wielkopolska Province and Poland, 2011-2013

\begin{tabular}{l|c|c|c|c|c|c}
\hline \multirow{2}{*}{ Territorial unit } & \multicolumn{4}{c}{ Total } \\
\cline { 2 - 7 } & \multicolumn{2}{|c}{2011} & \multicolumn{2}{c}{2012} & \multicolumn{2}{c}{2013} \\
\cline { 2 - 7 } & $\begin{array}{c}\text { number } \\
\text { of employees }\end{array}$ & $\begin{array}{c}\text { percent } \\
\text { of women }\end{array}$ & $\begin{array}{c}\text { number } \\
\text { of employees }\end{array}$ & $\begin{array}{c}\text { percent } \\
\text { of women }\end{array}$ & $\begin{array}{c}\text { number } \\
\text { of employees }\end{array}$ & $\begin{array}{c}\text { percent } \\
\text { of women }\end{array}$ \\
\hline Poland & 5186 & 66.4 & 5771 & 66.7 & 7211 & 62.1 \\
\hline Wielkopolska Province & 341 & 61.0 & 338 & 64.2 & 446 & 64.3 \\
\hline Eódz Province & 475 & 67.1 & 607 & 68,0 & 486 & 69.0 \\
\hline Mazovia Province & 1958 & 69.2 & 2592 & 67.4 & 2214 & 66.0 \\
\hline Opole Province & $*$ & $*$ & 36 & 69.4 & 39 & 64.1 \\
\hline
\end{tabular}

*Data excluded from public presentation because of statistical confidentiality protection Source: own study on the basis of the data from the CSO

Table 5. Employment in research and development activity (R\&D) in the field of biotechnology in scientific units by levels of qualifications in 2013

\begin{tabular}{l|c|c|c|c|c|c|c}
\hline \multirow{2}{*}{\begin{tabular}{c}
\multirow{2}{*}{ Territorial unit } \\
Poland
\end{tabular}} & \multirow{2}{*}{$\begin{array}{c}\text { Total number } \\
\text { of employees }\end{array}$} & $\begin{array}{c}\text { Title } \\
\text { of professor }\end{array}$ & $\begin{array}{c}\text { Degree } \\
\text { of habilitated doctor }\end{array}$ & PhD & $\begin{array}{c}\text { University } \\
\text { degrees }\end{array}$ & $\begin{array}{c}\text { Other } \\
\text { education }\end{array}$ \\
\cline { 3 - 8 } & 7211 & 10.9 & \multicolumn{4}{|c}{ Percent [\%] } \\
\hline Wielkopolska Province & 446 & 9.6 & 8.2 & 42.7 & 26.7 & 6.5 \\
\hline Małopolska Province & 355 & 11.3 & 16.1 & 38.8 & 37.0 & 6.3 \\
\hline Mazovia Province & 2214 & 17.5 & 7.6 & 35.5 & 37.5 & 10.6 \\
\hline Eódz Province & 486 & 7.4 & 9.9 & 36.2 & 31.3 & 15.2 \\
\hline
\end{tabular}

Source: own study on the basis of the data from the CSO

Table 6. Employment in the field of biotechnology in enterprises in 2011-2013

\begin{tabular}{l|c|c|c}
\hline \multicolumn{1}{c}{ Territorial unit/year } & 2011 & 2012 & 2013 \\
\hline Potal \\
\hline Wielkopolska Province & 1972 & 2046 & 2325 \\
\hline Lower Silesia Province & 145 & 154 & 234 \\
\hline Mazovia Province & 241 & 227 & 328 \\
\hline Kuyavian-Pomeranian Province & 27 & 22 & 11 \\
\hline \multicolumn{3}{c}{ Percent of women [\%] } \\
\hline POLAND & 41.5 & 43.5 & 44.1 \\
\hline Wielkopolska Province & - & 59.8 & 49.1 \\
\hline Lower Silesia Province & 29.9 & 34.0 & 27.7 \\
\hline Mazovia Province & 34.1 & 33.5 & 37.3 \\
\hline Kuyavian-Pomeranian Province & 85.1 & 40.9 & 54.5 \\
\hline
\end{tabular}

Source: own study on the basis of the data from the CSO 
counted for $43 \%$ and those with a master's or bachelor's degree for $27 \%$.

Analysis of the employees of scientific units in particular regions of Poland based on their qualifications shows that in Mazovia Province almost half of the employees had a Ph.D. degree (48.2\%). Also a higher percentage of employees with the title of professor were found in Mazovia Province (approx. 17\% of all the employees).

In 2013 in Wielkopolska Province, more than 230 people worked in enterprises associated with biotechnology (Table 6). Almost half of the employees were women (49\%). Disparities in the number of employees in different regions of Poland were observed. The biotechnology companies in the Mazovia Province employed 788 people, of whom $37 \%$ were women. On the other hand, in Lower Silesia, 27\% of the employees in the biotechnology companies were women.

\section{Potential for the development of biotechnology in Wielkopolska Province}

Stowarzyszenie Bioregion Wielkopolska, an association whose aim is to integrate and popularize the biotechnology industry, has created a high potential for development in Wielkopolska Province. It uses knowledge and expertise of employees connecting business and science. The association comprises 12 entities (Bioregion Wielkopolska). YouNick Technology Park acts as a hinterland of association. Companies that are members of this association belong to pharmaceutical, food, cosmetics, veterinary, medicine, and healthcare sector. The Bioregion Wielkopolska supports individual research and projects and R\&D activities of companies, commercializes their own projects, and takes part in external tasks.

Another center that creates great opportunities for the development of biotechnology is Wielkopolska Center of Advanced Technology in Poznan (WCAT). The center is a consortium of five universities of Poznan: Adam Mickiewicz University, which is the project coordinator, Poznan University of Life Sciences, Poznan University of Medical Sciences, Poznan University of Technology, and Poznan University of Economics. There are four institutes that function under the Polish Academy of Sciences: Institute of Bioorganic Chemistry, Institute of Plant Genetics, Institute of Human Genetics, and Institute of Molecular Physics. One of the WCAT's members is the Institute of Natural Fibers and Medicinal Plants, Poznan Science and Technology Park of the Adam Mickiewicz University Foundation and the City of Poznan. The integration of Poznan researchers will allow creating a knowledge-based economy. New technologies related to health, high-tech industry, and nanotechnology will be created by researchers and scientists.

All these centers play a very important role in the scientific community of Wielkopolska Province as they create opportunities for the development of the biotechnology sector in this region.

\section{Conclusions}

Wielkopolska Province has a high potential for research and development, the potential being created by human capital, represented by highly qualified staff. However, its influence on the development of innovation is negligible. Six universities in the Wielkopolska Province offer biotechnology in their academic programs. However, the research and development activities performed in Wielkopolska Province is still dominated by basic research.

As indicated in the Development of Wielkopolska Province (2012) document, it is significant for the development of innovation to take advantage of the research in economy. The support for the R\&D sector and its cooperation with enterprises should be an important part of Polish economy. Regional authorities recommended some directions in the field of bioeconomy, such as biotechnology and biochemistry and also nanotechnology. The most important factor is cooperation and the transfer of knowledge and technologies from scientific and research units. Availability of current information on the level of cooperation is an important issue and requires thorough analysis. Detailed data about each of the companies in Wielkopolska Province, including employment, production, income, or investment, should be collected during the interviews with entrepreneurs.

In 2013, there was a rise in the number of entities that conducted biotechnological activity in Wielkopolska Province. Research and development activity was carried out by 12 scientific units and 21 enterprises. Most of the activities conducted by those entities related to medical and industrial biotechnology. On the other hand, companies were involved in the production of materials, reagents, equipments, and cosmetics. 
In 2013 in Wielkopolska Province, the number of employees in the biotechnological sector of scientific units totaled 446. Majority of the employees were women (64\%). Pertaining to the level of qualification of the employees, it should be noted that the majority had a doctor's degree and higher education. Only slightly less than $10 \%$ of the employed had a professor title. The majority of research performed by scientific units is basic research.

In 2013 in Wielkopolska Province, 234 employees worked in biotechnological sectors for enterprises, of whom $49 \%$ were women. In 2013, expenditures on biotechnological activity amounted to more than 67 million PLN, being higher than that in the previous year.

\section{References}

Central Statistical Office of Poland (CSO), http://stat.gov.pl/ [retrieved: 20 Oct. 2015].

Kalbarczyk E., Woźniak E., Kalbarczyk R. (2015) Wsparcie instytucjonalne biogospodarki ${ }_{W}$ Wielkopolsce - wstępne wyniki badań. Stud. Ekonom. Region. 8(3): 31-50.

Łobejko S., Sosnowska A. (2013) Komercjalizacja wyników badań naukowych. Praktyczny poradnik dla naukowców http://www.msodi.mazovia.pl/upload/files/pdfy/Komercj alizacja\%20wynikow\%20badan\%20naukowych.pdf [retrieved: 15 Oct. 2015].

Ministry of Science and Higher Education Report, 2007, https://www.nauka.gov.pl/g2/oryginal/2013_05/18659c 24f81283894d0b4c489e099cb1.pdf [retrieved: 20 Oct. 2015].
OECD, http://www.oecd.org/sti/biotech/ [retrieved: 15 Oct. 2015].

Polish Information and Foreign Investment Agency- Report - Pharmaceuticals and biotechnology sector in Poland, 2011 file://C:/Users/Ewa\%20Wo\%C5\%BAniak/Downloads/ 4.1.8\%20Sektor\%20farmaceutyczny\%20i\%20biotechnologi czny\%20w\%20Polsce.\%20Pr.pdf [retrieved: 22 Dec. 2015].

Roche Report - The social commitment of Roche Poland, $2014 \mathrm{http}: / /$ www.roche.pl/content/dam/roche_poland/pl_ PL/images/raport2014/Roche\%20Raport\%202014.pdf [retrieved: 20 Jan. 2016].

The Regional Innovation Strategy for Wielkopolska 2010-2020, http://www.wrpo20072013.wielkopolskie.pl/zalaczniki1/ 2012//Regionalna_Strategia_Innowacji_dla_Wielkopols ki_na_lata_2010-2020.pdf [retrieved: 20 Oct. 2015].

The Wielkopolska Province Development Strategy 2020, https://www.umww.pl/ attachments/ article/11584/Zaktu alizowana\%20Strategia\%20Rozwoju\%20Wojew\%C3\%B3d ztwa\%20Wielkopolskiego\%20do\%202020\%20roku.pdf [retrieved: 20 Oct. 2015].

Website: www.biotechnologia.pl [retrieved: 20 Dec. 2015].

Website: Bioregion Wielkopolska, http://www.bioregionwielko polska.pl/ [retrieved: 20 Oct. 2015].

Website: DNA Research Center http://cbdna.eu/ [retrieved: 22 Jan. 2015].

Website: GlaxoSmithKline http://www.gsk.com.pl/ [retrieved: 20 Jan. 2016].

Website: WCAT - Wielkopolska Center of Advanced Technologies http://wczt.pl/ [retrieved: 19 Dec. 2015]. 